\title{
Geopolitics of geographical urbanonyms: evidence from Ukrainian cities
}

\author{
Oleksiy Gnatiuk*, Anatoliy Melnychuk
}

Taras Shevchenko National University of Kyiv, Department of Economic and Social Geography, Ukraine

* Corresponding author: alexgnat22@ukr.net

\begin{abstract}
This article focuses on geographical urbanonyms in Ukraine - names of streets, squares, lanes, etc. that refer to the names of other geographical objects like cities, regions, countries, or continents. It shows the role of geographical urbanonyms as a powerful instrument used by political regimes to shape political identity by constructing and legitimizing borders between "us" and "them" at different spatial scales. The analysis revealed a significantly higher presence of geographical urbanonyms in Ukraine compared to former state socialist countries in Central Europe. The widespread presence of street names related to the former USSR proves the absence of post-Soviet decolonization in semiotic space, going beyond the pure decommunization, in the majority of Ukrainian cities since 1991. Regional differences in the dynamics, distribution and structure of geographical urbanonyms in Ukraine are explained by the historical, cultural and (geo)political divisions.
\end{abstract}

\section{KEYWORDS}

urban toponyms; geographical urbanonyms; geopolitics; Ukraine

Received: 16 July 2020

Accepted: 23 September 2020

Published online: 3 November 2020

Gnatiuk, O., Melnychuk, A. (2020): Geopolitics of geographical urbanonyms: evidence from Ukrainian cities.

AUC Geographica 55(2), 255-268

https://doi.org/10.14712/23361980.2020.19

(c) 2020 The Authors. This is an open-access article distributed under the terms of the Creative Commons Attribution License (http://creativecommons.org/licenses/by/4.0). 


\section{Introduction}

Recent literature in the field of critical toponymy focuses mostly on commemorative place names. Typically, commemorative toponyms include names honouring prominent personalities, events, organizations and institutions, abstract ideologies, while other toponyms are classified as descriptive, possessive, and euphemistic (Stewart 1954). While the role of commemorative place names as an instrument of memory and identity policy is not questioned, the symbolic (including political) significance of other categories of toponymy is often underestimated or overlooked. However, as Rose-Redwood (2017) has shown, any act of naming and renaming has a commemorative dimension.

In this paper, we want to draw attention to geographical group of urbanonyms - urban place names that derive from the names of geographical objects. On the example of Ukraine, a post-Soviet country with turbulent history, contingent and contradictory memory policy (Shevel 2011; Portnov 2013), ongoing processes of official legally-binding decommunization and unprompted voluntary decolonization, we want to show their roles both as cultural indicators and technology of power used by national and regional political regimes to assert their authority and symbolic power.

Hereinafter we use a term 'toponymy' to refer a set of toponyms (place names) within a specific territory, except for a phrase 'critical toponymy' signifying critical approach to the study of place names as belonging to structures of power and identity (Berg and Voulteenaho 2009).

\section{Theoretical and methodological background}

\subsection{Urban toponymy as a mimicry of city- world relations}

According to Lappo (2012), the city is a mirror of the region. The point is that cities reflect the specific characteristics, successes and problems of the surrounding regions. However, this role of the mirror is not limited to social, demographic, or economic relations. Any city is a symbolic (semiotic) representation of the surrounding space. A set of urban verbal and visual texts (signs, names of streets, restaurants, metro stations, advertising images, monuments, ethnic neighbourhoods, etc.) resembles a topographic model of the world (Nikolaeva 2014). The larger is the city, the more important role it plays in the national and world hierarchy, the wider and clearer resemblance relationships with its own region, country, and the whole globe are realized in its semiotic space.

Urban toponymy as the most common and most simple (to perceive and comprehend) form of urban semiotics plays a key role in this representation. Toponyms are not merely abstract names in the spatial structure of cities, but also represent the construct of social and power relations, through which the identity of the city and society is being formed (Berg and Voulteenaho 2009). E.g. as Smirnov (2013) points out, the toponymy of St. Petersburg in different historical epochs reflected and reflects the relations of the city and its inhabitants with foreign states, natives of these states, cities with which St. Petersburg is somehow connected, illustrating the changing assessment of certain epochs, other states and related statesmen and representatives of culture. Street names in Grozny reflect the city's socio-cultural relations with the Chechen Republic, the Caucasus region and the all-Russian geographical and cultural context (Thakahov 2019). Paraphrasing the apt statement about a streetscape as a political cosmos (Rose-Redwood, Alderman, and Azaryahu 2017b), the urban toponymy may be deemed to be a microcosm reflecting the macrocosm of the Universe through the cultural and political lenses.

\subsection{Geographical urbanonyms and their role in the symbolic marking of space}

The semantics of a large group of urbanonyms directly refers to the names of other geographical objects: cities, regions, countries, continents, etc. According to semiotic classification, used by Stiperski et al. (2011) and then by Bucher et al. (2013), these urban placenames are treated as geographical toponyms and include names derived from rivers, cities, regions, countries, mountains, islands, etc. Dala Costa (2020) follows the similar approach and defines such toponyms as referencing geographical places like cities, villages, countries, mountains or gorges. This group should not be confused with so-called location urbanonyms, deriving from important sites, places and objects within the city. In the literature these two groups of urbanonyms (geographical and location) together are treated as "geography urbanonyms" (Stiperski et al. 2011; Bucher et al. 2013) or "topographical urbanonyms" (Gnatiuk 2018). Geographical urbanonyms may be classified based on the location of the relevant geographical objects, e.g. into regional, national, foreign, etc. More detailed classification is also possible, e.g. street elsewhere with the name derived from Brno, Czech Republic, may be classified as Moravian, Czech, and European geographical urbanonym.

Urbanonyms have two key functions: orientation (utilitarian) and symbolic (commemorative) (Azaryahu 1990). Geographical urbanonyms are a good illustration of this thesis. Some of them are mainly utilitarian: e.g. a street leading to a certain town or village was given the respective name. Commemorative, in particular geopolitical considerations did not play a significant role in the creation of such 
street names. It can be assumed that such utilitarian geographical urbanonyms reflect the most important and stable relationships of the city with the outside world in certain historical epoch. Not surprisingly, utilitarian geographical urbanonyms are represented mostly by "regional" and, less frequently, "national" names. On the other hand, symbolic geographical urbanonyms are assigned in order to reflect a certain geographical object in the symbolic space of the city, while direct economic, social, or demographic connections of the city with this geographical object recede into the background.

The most common motivation for symbolic geographical place names is to emphasize belonging to a certain socio-cultural and/or political space: the power of naming is often the first step in taking possession (Todorov, quoted in Robinson 1989). The cities of a certain country naturally have some streets named after other cities of the same country: such toponymic policy cements the national cultural and political space. At the same time, the indigenous population of the colonized territories often perceives such toponyms as culturally alienated, imposed by the colonizers, as evidenced by the attempts to restore toponymic justice and return the right to name to the indigenous population (Rose-Redwood, Alderman, and Azaryahu 2017a). In this sense, developing the argument by Marin (2017), we should recognize that toponymic inscription involves not only chronotopic, but also direct chorotopic boundary-making, constructing and legitimizing borders between "Us" and "Them" in space - colonial/indigenous, national/foreign, East/ West, etc. All cultures start out from the division of the world into an internal ("Our") space and an external ("Their") space (Lotman 2000 [1996]), and geographical toponyms are useful instrument to mark this division.

Thus, geographical place names, making political ideologies to appear as the "natural order of things" in the eyes of ordinary citizens (Azaryahu 2009), represent a powerful instrument for constructing political identity, in particular through colonization/ occupation and decolonization/deoccupation, and have repeatedly constituted a subject of critical toponymy studies. In particular, in colonial Singapore, a lot of official street names were derived from British places (counties, urban centres, seaside resorts), as well as some cities elsewhere from the British Empire (Yeoh 1996, 2017). A major transport hub in Budapest was named as Moscow Square in 1951, and in 2016 original historical name was returned to that place (Palonen 2017). Some Arab geographical urbanonyms were replaced in Haifa after the creation of Israel (Azaryahu 2017). In the late-nineteenth century, many streets in Belgrade, Serbia, were renamed after geographical places important in Serbia's national history and major cities in the Slav world. Remarkably, if a virtual map were drawn connecting the places "remembered" in the new street names, the borders of medieval Serbia would come to the forefront; with this project, the nationally conscious intellectuals hoped to bring Belgrade's population to identify itself with the places remembered in the new street names so that they would accept them as "their own" (Stojanović 2007). Almost all street names in Zagreb referring to Serbian and Russian cities were changed in the early-1990s in order to erase the "negative others" from the streetscape of Croatian capital. Simultaneously, the role of Zagreb as the capital city of independent Croatia was symbolically manifested by an increased number of street names referring to Croatian territory. The renewed map of Zagreb inscribed also belonging to the common cultural sphere of Central Europe and common spiritual culture, as well as new geopolitical friendships (Šakaja and Stanić 2017). The new street names in the West Mostar (Bosnia and Herzegovina) after renaming in 1990s emphasize a shared history with the motherland of Croatia by recalling, among else, names of important Croat cities (Palmberger 2017). In Riga, Latvia, the names of several Hanseatic cities were concentrated in the living area of Mežaparks, but after the beginning of the World War I - particularly in 1915 - the names of these streets were all changed into names coming from Russian place-names. However, after the Soviet Union collapse, the names of Hanseatic cities were given once again to the new streets in Mežaparks (Balode 2012).The recent study on Minsk toponymic system (Basik and Rahautsou 2019) showed that the Russian (in particular, Siberian) street names, being irrelevant to the locals, were implanted into the urban semiosphere in Soviet period forming an artificial toponymic identity separate from the identity of the place; at the same time, place names related to the world outside the former USSR represent only $0.9 \%$ from the total of geographical urbanonyms. All these findings witness the role of geographical urbanonyms as an instrument to create and recreate symbolic spaces, in particular differentiating between geopolitically "our" and "their" space.

However, there are few studies focusing on geographical urbanonyms as a specific phenomenon. The exception is the above-mentioned paper by Balode (2012) that thoroughly examines a body of geographical urbanonyms in Riga. In addition to the above-mentioned observation, the paper tells the reader some other interesting facts, including the following: 1) quantitative prevalence of regional and national urbanonyms and low proportion of "foreign" ones, 2) the majority of the latter refer to the toponymy of the closest neighbour countries (Estonia, Lithuania, Poland, etc.), 3) toponymy of Russian (and Belarusian) origin is very rare nowadays due to the renaming of streets in the first years of Latvian independence after1990, but in Soviet times Russia-related street names were quite numerous, 4) some foreign placenames mentioned in urbanonymy were replaced by Latvian toponyms during the first independence of 
Latvia. These facts conform to the concept of urban toponymy as a mimicry of city-world relationships and support the idea that such a mimicry is geopolitically shaped. However, although findings are valuable for current research, the author of the cited research follows rather descriptive than critical approach: geographical place names are simply listed without clear explanation of circumstances and factors, including political regime changes, influencing their occurrence and disappearance; the relevant conclusions are left up to the reader.

\subsection{Ukrainian urban toponymy in the discourses of decommunization and decolonization}

After the collapse of the socialist regimes, most countries of Central and Eastern Europe experienced transformations of urban toponymy aimed at the elimination of communist ideology and the formation of a new national identity (Light 2004; Gill 2005; Czepczyński 2008; Palonen 2008; Crljenko 2012; Light and Young 2014). Ukraine was not an exception from the general trend, but the toponymic process there had certain national specificity and consisted of two qualitatively heterogeneous stages. The first stage (1991-2014) resulted in a voluntary and weak decommunization of urban toponyms based on the initiatives of local governments with clear regional differences. In the Western Ukraine, especially in Galicia, almost all names related to the communist regime were erased at this early stage; in Central Ukraine the renaming was limited and related to the streets in the central parts of cities and streets that carried the names of the most odious communist regime representatives; in Southern and Eastern Ukraine, with some exceptions, the renaming of streets practically did not occur, and the communist toponymy was preserved almost entirely (Riznyk 2007). After the Revolution of Dignity, in 2015, the Ukrainian Parliament adopted so-called Decommunization Package of Laws, providing the criteria for communist toponymy that should be erased, as well as legal details of renaming procedure. This caused the second wave of communist street names liquidation that was much more massive and covered the entire territory of Ukraine due to its mandatory nature.

Critical comprehension of these waves of decommunization and accompanying toponymic processes in the literature takes place mainly in the context of the politics of memory in modern Ukraine. In particular, the following aspects are addressed: 1 ) differences between regional models of a new national identity building (Gnatiuk 2018), 2) spatio-temporal aspects of the urban toponymy transformation (Takhtaulova 2017; Gnatiuk and Melnychuk 2020; Pavlenko 2020), 3) key discourses / approaches to decommunization: "historical nostalgia", "nationalistic" and "decolonization" (Males 2016; Males and Deineka 2020), 4) implementation of memory policy in a specific region or city
(Hrytsak 2007; Vengryniuk 2012; Mahrytska 2013; Neher 2014; Fernos 2018; Savchenko and Takhtaulova 2019; Gnatiuk and Melnychuk 2020; Males 2016; Males and Deineka 2020; Kudriavtseva 2020; Pavlenko 2020), 5) influence of the axiological status of a place within a city on the politics of memory (Gnatiuk and Glybovets 2020), 6) legal and organizational features of the decommunization process, principles of choosing new names (Karoyeva 2017), 7) problematic aspects of state toponymic policy (Hyrych 2013). The toponymic space of the city is considered as one of the platforms for the ideology building in contemporary Ukraine, which is realized through social and state mechanisms of consensus and reconciliation (Takhtaulova 2015), as a symbolic capital (Males 2016) and as a spatial projection of the societal axiological system (Gnatiuk and Glybovets 2020).

However, geographical urbanonyms, despite their powerful significance for the formation of the symbolic urban space, remain on the periphery of decommunization discourse. The reason is the lack of their inalienable ideological connotations, although the name of "Moscow Street" may evoke associations with the communist regime, and the name of "German Street" - with the Nazis. Perception of such names as problematic, contradictory, undesirable, etc. is possible only within the discourse of decolonization, according to which current changes in the symbolic space in Ukraine should not end with the elimination of communist ideology, but should be continued in order to erase a memory of the "colonial" past of Ukraine as a part of the USSR, the Russian Empire, etc. (Males and Deineka 2020). Nevertheless, currently there is no official policy of "decolonization" in Ukraine: the available examples are spontaneous and voluntary initiative at the local level, just as decommunization until 2015. The voluntary nature of toponymic decolonization (mainly understood as de-Russification) makes it an attractive and objective tool for the study of changing self-identification of Ukrainians. After all, communist toponyms disappeared from the streetscapes in the East and South of the country not because the local population or local elites demanded it, but because the decommunization became mandatory. Cases of decolonization testify to the meaningful, mature (albeit debatable) nature of toponymic changes on the part of the local population and local political elites. This is shown both by the examples of Lviv, where de-Russification took place already in the 1990s (Hrytsak 2007), and Kyiv, where the relevant discourse unfolded after the Revolution of Dignity (Males 2016; Males and Deineka 2020).

\section{Data and methods}

In order to explore general representation and regional distribution of geographical urbanonyms in Ukraine, we used the data from the 40 largest cities 
of Ukraine, representing all administrative regions. The number and the share of geographical urbanonyms among all street names in 2020 were calculated for each city. Then, for each city, the structure of geographical urbanonyms was determined in terms of the location of their denotations (i.e. geographical objects from which names are derived). Depending on the geographical location of denotations, all geographical urbanonyms were divided into the following categories: "local" - within the same administrative region of Ukraine as the city itself; "Ukrainian" - within modern Ukraine; "Soviet" - within the former USSR; "Socialist Europe"- in the European countries of the former socialist camp; "Capitalist Europe"- in the other European countries; "other"- in the rest of the world. This classification is somewhat conditional and does not reflect the variety of circumstances of each place name origin, e.g. some names classified as "Soviet" may originated long before the Soviet Union or after its collapse. However, this approach is the most relevant for the modern historical context, when Ukraine is an arena of competition and interaction of (pro) European identity on the one hand and (post) Soviet and (pro) Russian identity on the other, so we decided to use it, addressing these problematic moments in the analysis. Also, we calculated the share of "Soviet" urbanonyms renamed during the years of independence (1991-2020) in order to identify individual and regional differences in post-Soviet decolonization of urban toponymy.

In order to trace and explain the regionally specific dynamics of the emergence and disappearance of geographical urbanonyms, we chose three cases - large cities, each representing a separate part of the country with a specific cultural and political background and different approaches to toponymic policy: Lviv (Western Ukraine), Kyiv (Central Ukraine) and Dnipro (Eastern Ukraine). Furthermore, denotations of geographical urbanonyms for each case city were mapped: point geographical objects (cities) were indicated as points in their actual locations, and linear and planar objects were replaced by points located in their geometric centres. In this way, we tried to visualize the mental map of the "intimate" world, which the inhabitants of each of these cities may shape under the influence of geographical street names.

Information on the naming, renaming and liquidation of city objects was obtained from the following sources: 1) official documents of local governments and local authorities, 2) directories and databases (e.g. Official Directory of the Streets of the City of Kyiv, electronic directory "Streets of Lviv" of the Centre for Urban History of Central and Eastern Europe), 3) maps and plans of cities for different years.

Thus, in the present research we applied the elements of quantitative interpretation, the comparative analysis, as well as the cartographic and archival methods. We tried to follow, at least partially, critical toponymy approach, i.e. not only to describe the spatial, structural and temporal idiosyncrasies of geographical urbanonyms in Ukraine, but to link them to key (geo)political actors, epochs and shifts, as well as to the geographic, socio-political and cultural factors and circumstances, demonstrating the role of such toponymy in the ideology building and memory policy of the ruling political regimes, totalitarian or democratic.

\section{Results and discussion}

\subsection{Geographical urbanonyms at national and regional scale}

"Soviet" urbanonyms are the most common category of geographical street names in the totality of the studied cities $(40.3 \%)$. The second position is taken by "Ukrainian" urbanonyms (35.3\%), the third - by "local" urbanonyms (18.6\%). These three categories make up the vast majority of the total number of geographical urbanonyms and are present in all analyzed cities. The share of all other categories is slightly more than $5 \%$, and the most numerous of them are those related to the former socialist Europe $(3.3 \%)$ and other European countries (1.5\%).

The share of geographical street names tends to increase with the size of the city: it varies from $10-15 \%$ in cities with a population of up to 500,000 to $25-30 \%$ in larger cities (on average). This can be explained by two reasons: 1) the toponymy of large cities reflects their more developed spatial relationships, while smaller cities are mostly attached to a purely local context; 2) geographical map was a useful source for street names in the period of a rapid growth of large cities. Also, these figures indicate that geographical urbanonyms are much more widespread in Ukraine compared with the other CEE countries: in study by Bucher et al. (2013) their share was $0-16 \%$, and in study by Stiperski et al. (2011) - 2-9\%. However, Ukrainian figures are similar to that of Minsk 18.3\% (Basik and Rahautsou 2019).

The share of geographical urbanonyms also shows a strong dependence on the region (Fig. 1). If in the west, in the centre and partly in the south it is equal to $0-10 \%$ in the cities with a population of up to 500,000 and $10-15 \%$ in the larger cities, in the east (especially in Donbas, Dnipro and Kharkiv regions) these figures are $15-25 \%$ and $20-30 \%$ respectively (on average).

The structure of geographical urbanonyms also shows regional differences (Fig. 1):

- In the western and central parts of the country, the share of "local" names is high: it does not fall below $20 \%$, and in 7 cities out of 17 it exceeds $50 \%$. In this respect, the cities of these regions resemble the case of Riga (Balode 2012). Also, high proportion of "local" street names is observed in the Crimea. In the rest of the southeast it does not exceed $20 \%$, and in large cities like Dnipro, Zaporizhia and Kryvyi Rih it is less than $10 \%$. 


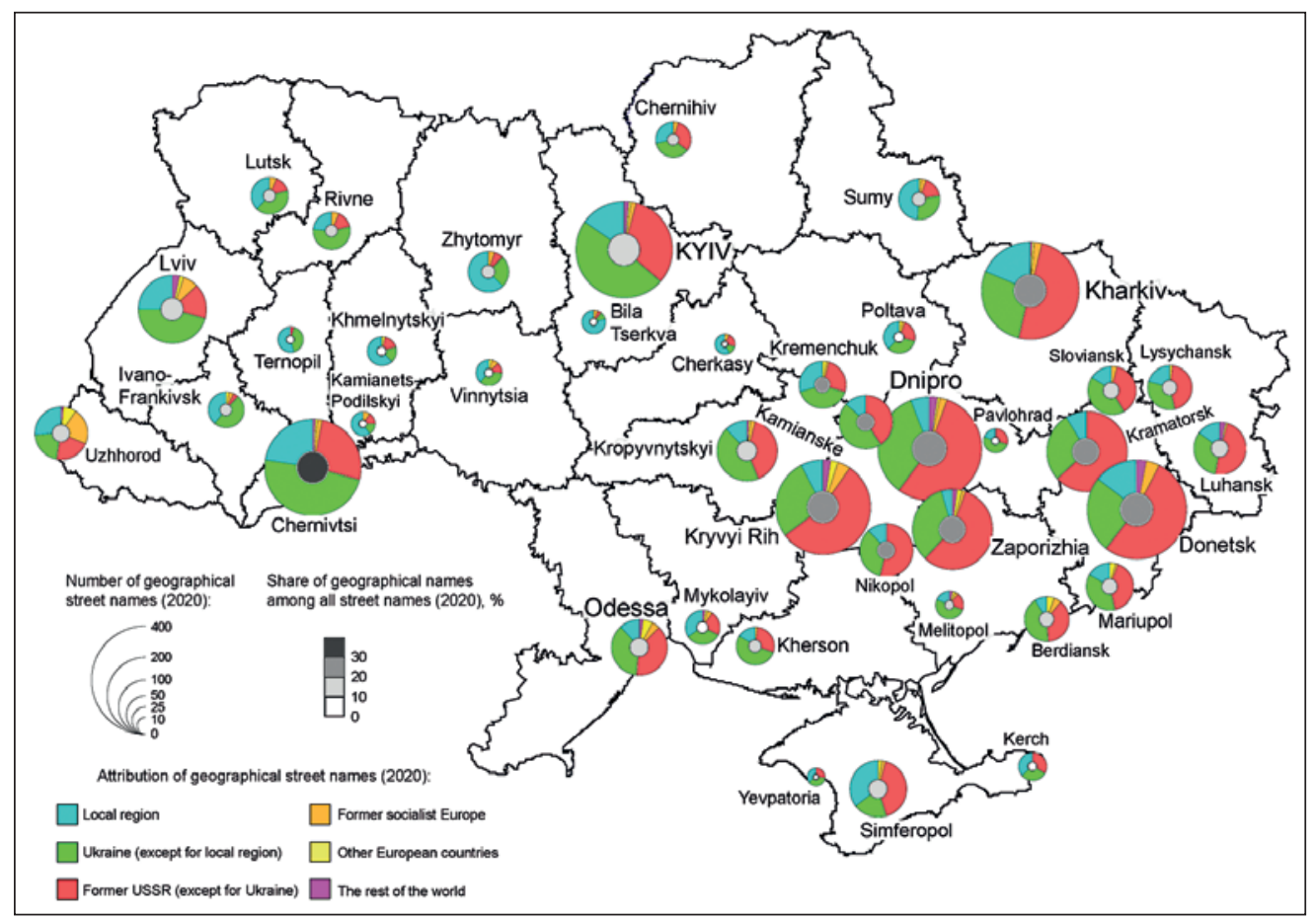

Fig. 1 Number, share and structure of geographical street names.

- The share of "Ukrainian" names takes the largest values in the cities of the western and central parts of the country. In particular, in Galicia, Volhynia, Bukovina, as well as in Kyiv, it is close to $50 \%$ or slightly higher. A similar situation is observed in some cities of the southern part. At the same time, in other cities of the southeast, the share of these urbanonyms does not exceed $20 \%$, and the lowest rates are typical for some cities in the central part (10-15\%). Nevertheless, distribution of "Ukrainian" urbanonyms is characterized by the smallest interregional disparities.

- The share of "Soviet" urbanonyms shows the strongest interregional disparities and the clearest spatial pattern. The smallest values are observed in the west and centre of the country, where in the vast majority of cities they do not exceed $30 \%$. In the south-east, the share of "Soviet" names does not fall below $30 \%$, and in some cities of Donbas and Prydniprovia it is above $50 \%$ or close to this figure. The exceptions are Kerch and Yevpatoria in Crimea, as well as Melitopol (less than 30\%).

- "Socialist Europe" urbanonyms are slightly more common in the cities of the west (with the absolute record in Uzhhorod - 22.1\%) and centre compared to the south and east. "Capitalist Europe" street names are relatively evenly distributed, with the highest values in Uzhhorod (8.4\%) and Odessa (5.6\%). Urbanonyms associated with the rest of the world have no obvious regional patterns of distribution and are concentrated mainly in the largest cities with a population of over 500,000 .

\subsection{Geographical urbanonyms as markers of Sovietization and post-Soviet decolonization}

Regional differences in the structure of geographical street names reflect the geopolitical past of different parts of the country - their belonging to the Austro-Hungarian and Russian empires, Poland, Czechoslovakia, Romania, and the Soviet Union. However, the influence of these geopolitical agents is asymmetric: "Soviet" names predominate over urban names associated with the European context almost throughout the country. Only in two cities of Western Ukraine, Uzhhorod and Ivano-Frankivsk, "European" toponymy prevails over "Soviet", and more or less balanced situation is observed also in other cities of the west and the centre of the country. In the rest of the territory, and especially in Donbas and Prydniprovia, "Soviet" toponymy is many times superior to "European" and, in some cases, to "Ukrainian" together with "local". Moreover, much of "European" names arose due to commemorating Soviet satellites, although it can be assumed that this aspect is not currently a key to the public perception of these urbanonyms. Thus, the everyday practices of the inhabitants in the majority of Ukrainian cities still take place in a continuous matrix of "Soviet" toponyms, and the former Soviet Union, including the Arctic, Kamchatka, Siberia and Central Asia, have every chance to be perceived as familiar, close, and intimate territories, while Europe and other regions of the world practically fall out of this mental map. In this respect, Soviet geographical place names proved to be a relatively stable category 
of toponymy, illustrating a kind of the toponymic continuity phenomenon considered by Light and Young (2017), Chloupek (2019) and Rusu (2020).

However, the reason for such a disproportionately wide presence of "Soviet" geographical street names is not only the special commitment of the Soviet regime to the use of toponymy as an ideological instrument, but also the fact of the most intensive demographic and spatial growth of Ukrainian cities in the Soviet era (Rowland 1983; Becker, Mendelsohn, and Benderskaya 2012). As will be seen from the analysis of cases, the practice of mass use of geographical urbanonyms in Ukraine became typical during the period of intensive spatial urban growth in the second half of XX century. Newly created streets and homonymic streets of former suburban settlements, merged with the city, required a lot of new names, and a map of the Soviet Union was a convenient source of them. The importance of such a naming practice as an instrument of identity may or may not be realized by officials, but eventually the city map became a reflection of the map of the "Great Soviet Motherland" and its geopolitical satellites. Accordingly, the larger is the city, the smaller, on average, is the share of "local" geographical urbanonyms that appeared spontaneously and performed a utilitarian function, and the larger is the share of geographical urbanonyms that have no direct relation to the city.

The widespread presence of "Soviet" geographical names on the maps of the majority of Ukrainian cities also indicates that the process of decommunization in Ukraine in most regions was not accompanied by the process of decolonization of public space. This fact becomes even more obvious when analyzing the number and the share of "Soviet" street names erased in 1991-2020 (Fig. 2). In fact, such decolonization (which largely meant de-Russification) took place only in the cities of Western Ukraine, where "Soviet" geographical place names were mostly eliminated along with communist names already in the 1990s, while in the rest of the country only some of the most odious names were eliminated. In many cities, in particular in the Crimea and Donbas, there were no "Soviet" urbanonyms that disappeared since proclamation of independence in 1991.

On the other hand, post-Soviet decolonization does not explain the sharp increase in the number and share of "Soviet" and other geographical urbanonyms in the southeast compared to the adjacent areas of the central part of the country. These differences were formed during the Soviet era. The assumption is that we are talking about the local specifics of the implementation of communist toponymic policy, when the naming decisions were made by local executive committees taking into account the predictable reaction of the local population. The transformation of the city map into a miniature map of the Soviet Union was quite acceptable for the urban communities of deeply Russified Kharkiv or Luhansk, but in Sumy or Poltava it was necessary to take more cautious steps, e.g. to rely more on the Ukrainian context and toponymy of neighbouring Soviet republics, avoiding the dominance of exotic place names from the Far East, Siberia or Central Asia. At least a partial coincidence of the outlined patterns with the basic electoral regions and fault-lines seems to be not accidentally (see Birch 2000; Katchanovski 2006; Clem and Craumer 2008; Osipian and Osipian 2012; Marples 2016; Diesen and Keane 2017).

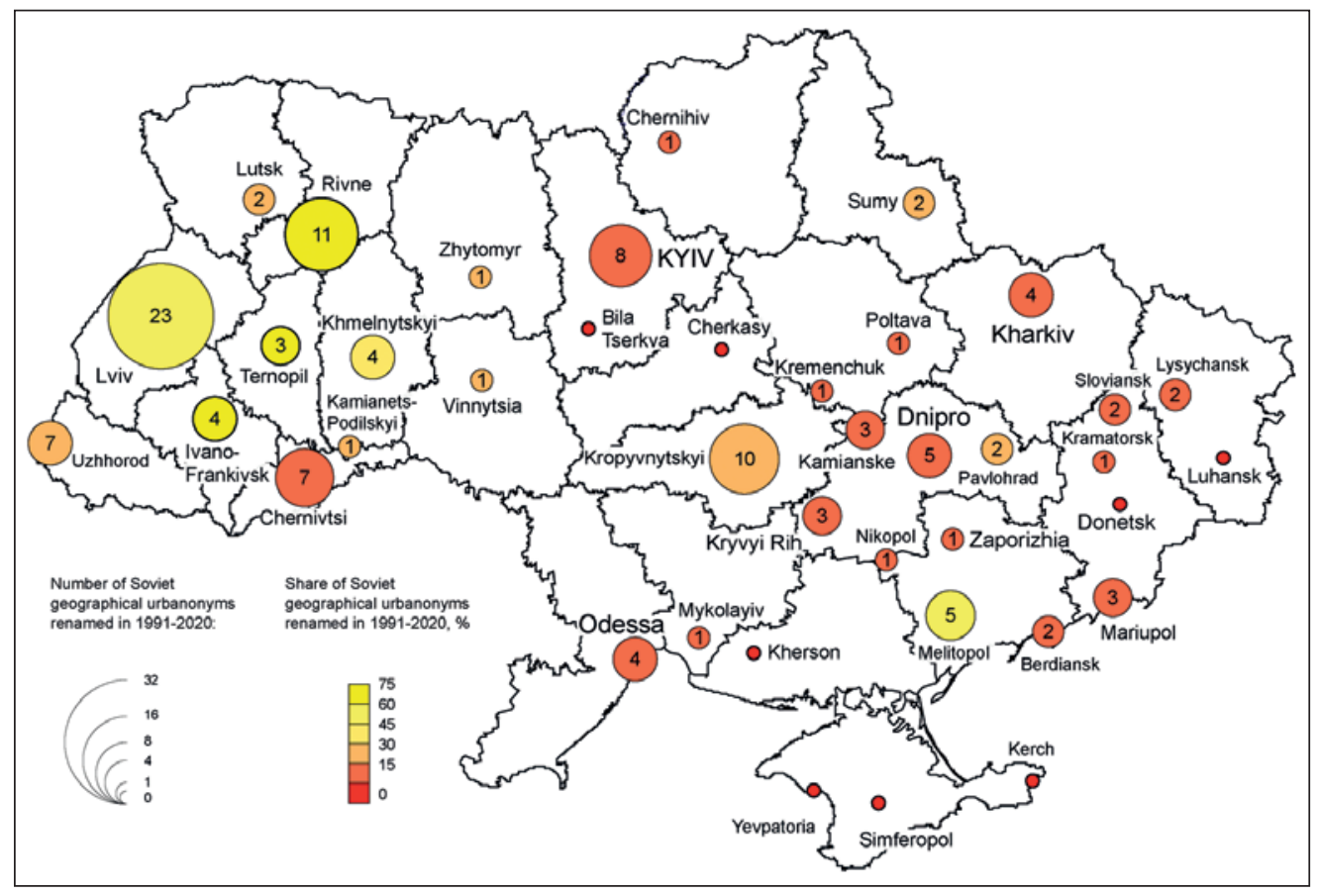

Fig. 2 Number and share of "Soviet" geographical street names renamed after 1991. 


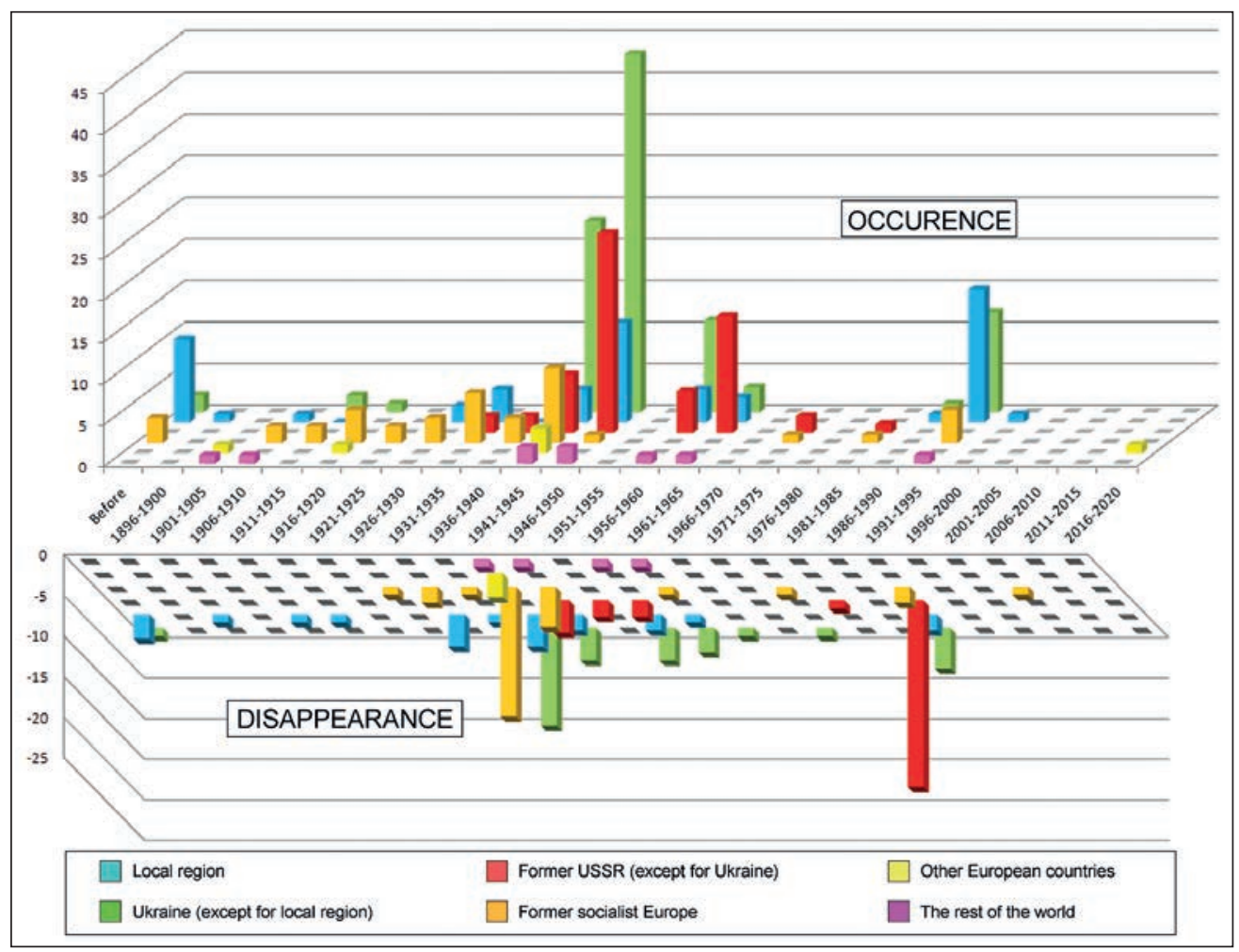

Fig. 3 Occurrence and disappearance of geographical street names in Lviv.

\subsection{Lviv: decolonization of public space as de-Russification}

Until the first quarter of the twentieth century, geographical street names in Lviv referenced predominately to the geographical objects located in the immediate vicinity of the city or the surrounding region, including the contemporary Lviv region, other territories of Western Ukraine and adjacent territories of modern Poland (Fig. 3). All these territories were parts of the Austria-Hungary.

When Galicia became part of Poland in 1920, new place names associated with Polish cities and territories began to appear regularly, overlapping "local" names in quantity and share, and symbolically marking the city as a part of the Polish state and cultural space. When the Nazis came to Lviv in 1941, many streets were named after German and Polish (already occupied) cities and regions.

In 1945-1950, after the second establishment of Soviet power on the territory of Western Ukraine, more than half of all "Polish" and especially "German" urbanonyms were eliminated. Instead, a large number of new geographical urbanonyms appeared with domination of "Ukrainian", followed by "Soviet" and "local". The second, slightly smaller wave of mass appearance of geographical urbanonyms occurred in 1955-1965 and was marked by an even greater proportion of "Soviet" names. After that, new geographical urbanonyms became rare until the end of the Soviet Union. Throughout the Soviet period, there were also separate names associated with the countries of the socialist camp, as well as Soviet geopolitical allies in Asia. Geographical toponyms played important role in the formation of the "Soviet" image of Lviv as an international city, in the sense of the creation of the Soviet nation (Hrytsak 2007). However, geographical urbanonyms, introduced since 1945, started to abundantly disappear in a short while, both due to the renaming and the transformation of the street network - liquidation or merging of streets. In this way, only about $75 \%$ of geographical urbanonyms that emerged in the Soviet era survived by the time of Ukraine's independence.

The first years after Ukraine's independence were marked by a radical transformation of the structure of geographical urbanonyms in Lviv. During this period, more than half of all "Soviet" urbanonyms were eliminated; geographical urbanonyms from the other categories also disappeared extensively, but appeared in even greater numbers. As a result, the number and share of "Soviet" urbanonyms decreased significantly, and the number and share of "local", "Ukrainian", to a lesser extent, and "European" urbanonyms increased.

The following features are noticeable on the map of denotations of modern geographical urbanonyms of Lviv (Fig. 5):

1) Denotations of "Ukrainian" urbanonyms are concentrated on the territory of Western Ukraine, comprising an "own region" for Lviv, and slightly smaller centres of their concentration are confined to the historical region of Middle Dnieper (hypothesis 
- emphasized importance of the region as a "heart of Ukraine"), and Black Sea region (hypothesis symbolic marking of that peripheral and Russified territory as Ukrainian).

2) "Soviet" toponymy is quantitatively almost balanced with "European". Especially many street names still refer to the territory of Poland, of which Lviv was a part for a long time, in particular in 1920-1939.

3) Denotations of "Soviet" toponymy are represented in most of the former Soviet republics, except for Russia, which is a "white spot". Exceptions are national autonomies, mostly marginal, inhabited by ethnic groups different from the Russians: Kuban and Taman (inhabited by descendants of Ukrainian Cossacks), Dagestan, the Kuril Islands (object of Russian-Japanese territorial disputes), Koryak Autonomous District, Chuvashia. It should be noted that before the Soviet Union collapse, the set of "Soviet" urbanonyms in Lviv was much more diverse and included a number of names relating to the territory of Russia.

Thus, going beyond the decommunization discourse, local toponymic policy in Lviv after 1991 was aimed at 1) decolonization in the form of de-Russification (via selective erasing of "Russian" street names) and imaging Russia as a "negative Other" (Molchanov 2016), 2) formation/revival of local and regional identity (by increasing the number of "local" urbanonyms), 3) formation of a single cultural space with the rest of Ukraine as a nation state (by increasing the number of "Ukrainian" urbanonyms). It is also specific that new geographical urbanonyms almost did not appear in Lviv after 1995. The last observation well illustrates the specifics of the toponymic process in the Western Ukraine - the accentuated commemorative principle of naming in order to commemorate the prominent figures of Ukrainian national culture and liberation movement (Riznyk 2007; Hrytsak 2007).

\subsection{Kyiv: de-Russified islands in the ocean of Soviet urbanonyms}

In Kyiv, until the middle of the XX century, "local", "Ukrainian" and "Soviet" street names appeared regularly (until 1922, "Soviet" names should be interpreted as related to the territory of the Russian Empire). Before the Soviet Union formation, "local" and "Ukrainian" urbanonyms clearly prevailed, but after that, the number of "Soviet" names increased, and the proportions of these three categories of urbanonyms became virtually equal. However, although new geographical urbanonyms emerged regularly, this toponymic practice was not very popular (Fig. 4).

In 1944, immediately after the liberation of Kyiv from the Nazis, systematizing of Kyiv toponymy resulted in more than fifty new geographical urbanonyms, mostly "Ukrainian" and "local"; the share of "Soviet" names was very low. Shortly after, in 1953 and 1955, two acts of large-scale systematization of Kyiv's urbanonymy took place, the most striking feature of which was the mass introduction of geographical urbanonyms (up to 200 new names). In the following decades the intensity of their occurrence gradually decreased from almost a hundred to several dozen per 5-year period. Among them "Ukrainian"

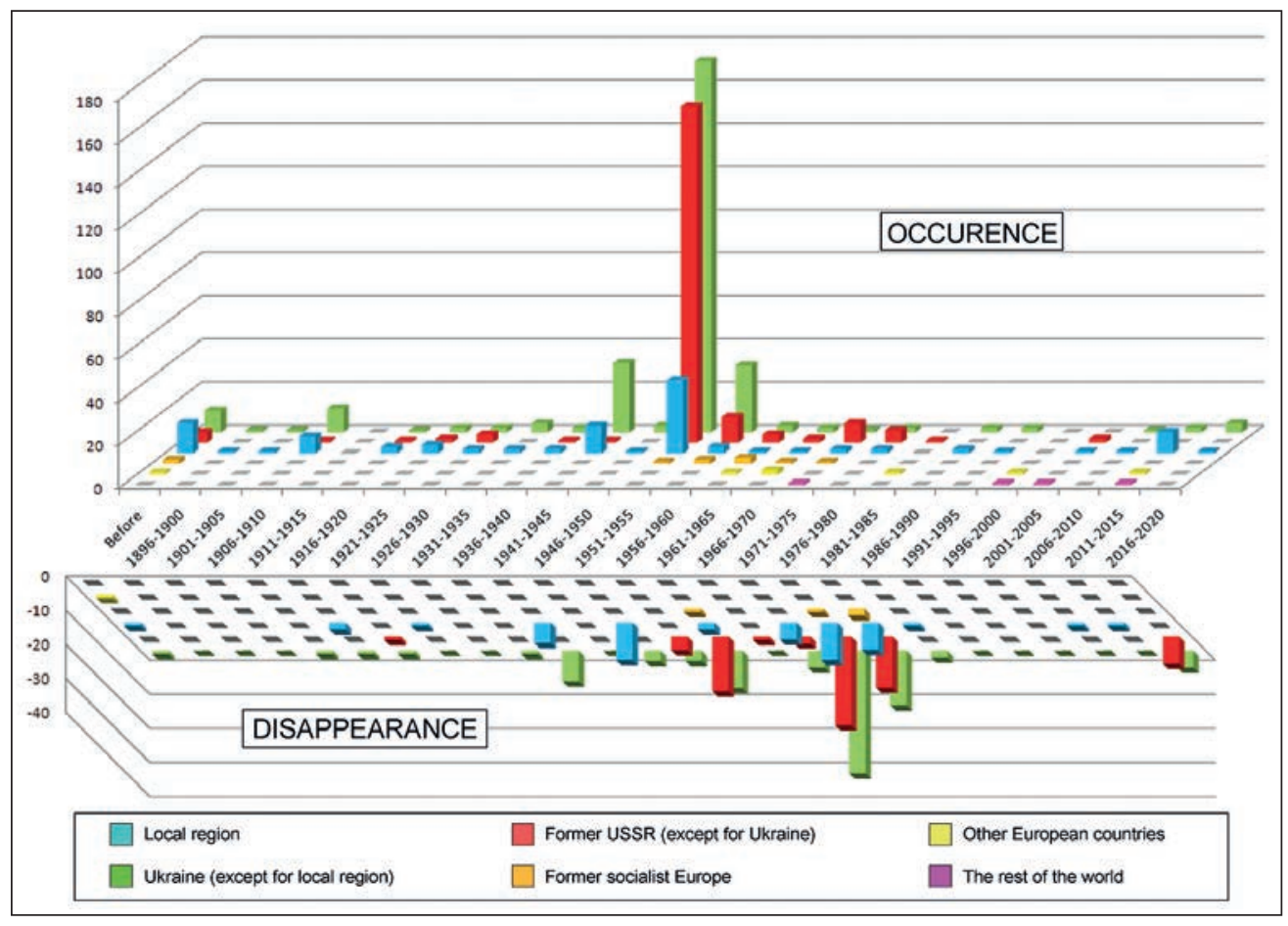

Fig. 4 Occurrence and disappearance of geographical street names in Kyiv. 
names dominated, followed by "Soviet" and "local". Street names after the cities and countries of the socialist camp, as well as the twin cities of Kyiv from the "capitalist" Europe, constituted a minority among new geographical street names.

Just as in Lviv, geographical urbanonyms of all categories in Kyiv began to disappear in large numbers shortly after their introduction. Particularly largescale waves of such disappearances took place in 1966-1970 and in 1975-1985. The main reason was liquidation of old low-rise housing in the process of building-up modernist housing estates.

In contrast to Lviv, radical changes in the number and structure of geographical urbanonyms after Ukraine's independence have not been observed in Kyiv. The trends of the 1900s were 1) break-up in the emergence of "Soviet" street names (the only exception was decommunization of Baku Commissars Street by renaming it after the Republic of Azerbaijan) and 2) almost complete cessation of the disappearance of existing geographical urbanonyms, including "Soviet": none of the latter disappeared from the map of Kyiv in 1991-2015. This phenomenon had two reasons, technical and ideological: the first was suspend in the construction of large residential estates, the second - the presence of Soviet place names on the city map was not perceived as a problem. At the same time, the liquidation of ideologically colored Soviet toponyms in Kyiv began in 1989 and lasted with variable intensity throughout Independence period (Gnatiuk and Melnychuk 2020).

The situation changed only after the annexation of Crimea and the armed conflict in the east of Ukraine, when Russia started to be perceived as an aggressor country. However, the changes were much more modest than in Lviv. Only up to a dozen of street names were changed, usually the most odious ones. In particular, Moscow Avenue, Moscow Square and Moscow Bridge were renamed; discourse analysis of the last two cases was performed by Males and Deineka (2020). Another illustrative example is Novorossiyska Street and Novorossiyskyi Lane: both were named after the city of Novorossiysk, but the term "Novorossiya" in Ukraine received a negative connotation due to its active use by pro-Russian separatists and some Russian officials and journalists with reference to the southeast of Ukraine ( $\mathrm{O}^{\prime}$ Loughlin, Toal, and Kolosov 2017). Thus, the process of toponymic decolonization is still eclectic in Kyiv, just as the decommunization before 2015 (Riznyk 2007).

On the other hand, after 2000, a little more than a dozen "local" and "Ukrainian" urbanonyms appeared in Kyiv. At first glance, it is possible to draw parallels between Kyiv and Lviv, but while in Lviv such names arose in the process of de-Russification and decommunization of urban toponymy, in Kyiv they appeared due to the naming of absolutely new streets. Another specificity of the Independence period, typical for Kyiv, but not for Lviv, was the regular appearance of street names related to Europe and the wider world context. In particular, historic names of European Square and German Street were restored; squares were named after Ankara and Santiago de Chile, and a street after the city of Bethlehem. This trend reflects the capital function of Kyiv, the space of which is designed to be not only a mimicry of home state, but also a matrix of international relations (Nikolaeva 2014). It is worth noting that structure of geographical street names in contemporary Kyiv is quite similar to that of another post-Soviet capital - Minsk (Basik and Rahautsou 2019).

The map of denotations of geographical urbanonyms of Kyiv has the following specific features (Fig. 5):

1) Denotations of "Ukrainian" urbanonyms are concentrated in the central part of the country ("own region" for Kyiv), while in the west, east and south their density is significantly lower. At the same time, in comparison with other cases, they are more or less evenly represented throughout Ukrainian territory.

2) "European" urbanonyms are significantly inferior to the "Soviet"; half of them are related to the countries of the former socialist camp (and, unlike in Lviv, Poland does not stand out against the general background), while the other half refer to the countries of the former capitalist Europe.

3) Denotations of "Soviet" urbanonyms are represented in almost all former Soviet republics, including, in contrast to Lviv, Russia. The distribution of denotations roughly reflects the population density map: most are concentrated in the European part of Russia, as well as Belarus, Transcaucasia and Ciscaucasia.

\subsection{Dnipro: untouched Soviet geographical toponymy}

The available data were too scarce to reproduce the integral continuous dynamics of the occurrence and disappearance of geographical street names in Dnipro just as for the other two cases. However, it may be stated that geographical urbanonyms were not numerous up to the XX century. Some streets were named after other cities of the Russian Empire, especially provincial centres, including those located on the territory of modern Ukraine. In the first Soviet decades, the practice of assigning geographical names was also not widespread; in addition, some geographical urbanonyms disappeared, leaving room for revolutionaries, Soviet statesmen and communist party figures. Just as in Kyiv, most of the geographical place names in Dnipro arose as a result of two decisions of the city executive committee in 1952 and 1956 respectively.

The Soviet Union collapse was not accompanied by the elimination of "Soviet" urbanonyms in Dnipro. Only after the official proclamation of decommunization in 2015, five "Soviet" street names disappeared from the city map. Four of them were formally subject 


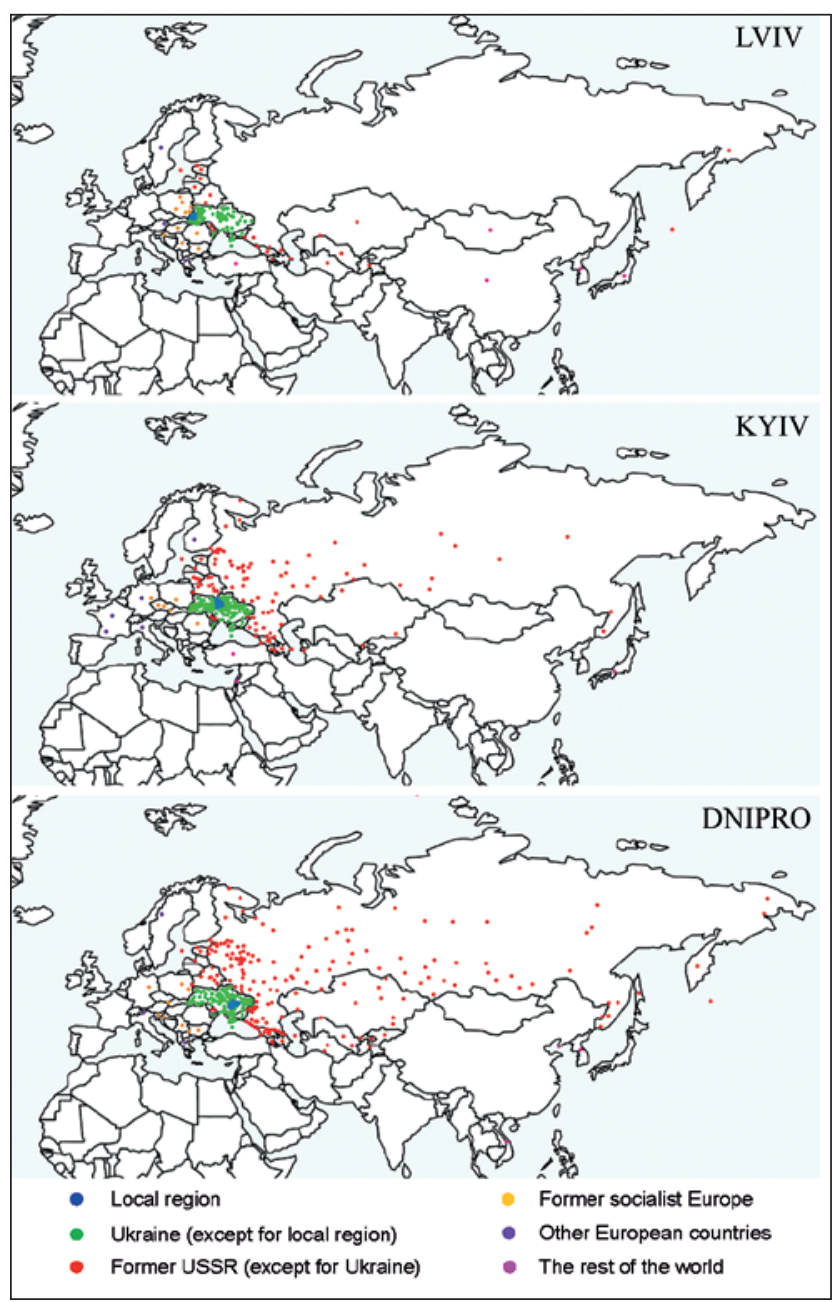

Fig. 5 Geographical distribution of the denotations of geographical street names in Lviv, Kyiv, and Dnipro.

to decommunization laws, and only the renaming of Moscow Street may be considered a full-fledged act of decolonization. At the same time, after 1991, several "local" and "Ukrainian" urbanonyms appeared in the city, many of them as new names for decommunized objects. The last aspect qualitatively distinguishes Dnipro from Kyiv: in the latter preference was given to the commemoration of prominent figures of history and culture, while in Dnipro, as in other cities in the south-east, ideologically neutral toponyms were prioritized (Gnatiuk 2018; Kudriavtseva 2020; Golikov 2020). Several urbanonyms after the cities and countries of Europe appeared during that period in Dnipro as well.

The map of denotations of geographical urbanonyms of Dnipro has the following specific features (Fig. 5):

1) Although the clear boundary of the "own" region for Dnipro cannot be identified, denotation of "Ukrainian" urbanonyms are more dense in the eastern part of the country.

2) Most of "European" names are related to the former socialist camp countries in the Central Europe and the Balkan Peninsula.
3) Denotations of "Soviet" urbanonyms are present in all former Soviet republics, except Lithuania. Compared to Kyiv, the centre of distribution density is clearly shifted to the east, with better coverage of Siberia, the Far East, the Far North of Russia, and Central Asia.

The case of Dnipro demonstrates the vitality of (pro)Soviet identity in Russian-speaking cities in south-eastern Ukraine (Pirie 1996). Having removed visible signs of communist ideology, the streetscapes of these cities continue to bear the imprint of the past inside the Soviet empire.

\section{Conclusions}

Geographical urbanonyms represent important and currently understudied phenomenon. Reflecting the most important and long-lasting connections of the city with the outside world, they form a kind of mimicry of the external environment in which the city exists. This resemblance is geopolitically distorted, since geographical urbanonyms are used by political regimes to denote "their" and "alien" territories. Such urbanonyms are especially important in the context of colonization and decolonization study, including in the post-Soviet space.

Applying critical toponymy approach together with the elements of quantitative, cartographic and comparative analysis, we considered the spatial, structural and temporal idiosyncrasies of geographical urbanonyms in Ukraine. We tried to show their use by political elites of different epochs for either cementing national state or promoting internationalization (under the communist rule). The current dynamics of the geographical urban place names was linked to the discourses of decommunization and decolonization which predominate in the Ukrainian politics of memory during the recent years. Virtual maps of geographical places, remembered in the cityscape of the selected case study cities, were drawn to show the geopolitically distorted image of the world imprinted in the symbolic space of the cities representing culturally different regions of the country.

In Ukraine, geographical urbanonyms were used during the XX century by the ruling elites of key political regimes to mark their own cultural and political space. Regional differences in the distribution and structure of geographical urbanonyms within Ukraine are explained by the historical, cultural and (geo)political divisions. They reflect both the influences of other states and the national identity policies, as well as regional and local readings of the latter. In contemporary Ukraine, geographical urban place names are good marker of cultural decolonization process, i.e. wiping out any reminders of the Soviet rule from the symbolic space, not limiting exclusively to the communist ideology. 
At the same time, the dynamics of geographical urbanonyms cannot be explained solely by the politics of memory or identity: demographic and spatial urban growth makes its contribution as well. However, the consequences of their introduction in large numbers on the public perception of the spatial cultural, civilizational and geopolitical structures should not be underestimated.

\section{References}

Azaryahu, M. (1990): Renaming the past: changes in 'city-text' in Germany and Austria 1945-1947. History and Memory 2(2), 32-53.

Azaryahu, M. (2009): Naming the past: the significance of commemorative street names. [In:] L. D. Berg, J. Vuolteenaho (eds.) Critical Toponymies: The Contested Politics of Place-Naming. Farnham: Ashgate, 53-70.

Azaryahu, M. (2017): Revisiting East Berlin and Haifa. A comparative perspective on renaming the past. [In:] R. Rose-Redwood, D. Alderman, M. Azaryahu (eds.) The political life of urban streetscapes: naming, politics, and place. Abingdon, U.K.: Routledge, 56-73, https://doi.org /10.4324/9781315554464-4.

Balode, L. (2012): Place-names in the urbanonymy of Riga: mark of identity. Studii si Cercetari de Onomastica si Lexicologie 5(1-2), 17-28.

Basik, S., Rahautsou, Dz. (2019): Toponymic politics and the symbolic landscapes of Minsk, Belarus. Geographia Cassoviensis 13(2), 107-120, https://doi.org/10.33542 /GC2019-2-02.

Becker, C., Mendelsohn, S. J., Benderskaya, K. (2012): Russian urbanization in the Soviet and post-Soviet eras. London: Human Settlements Group International Institute for Environment and Development.

Berg, L., Voulteenaho, J. (eds.) (2009): Critical Toponymies: The Contested Politics of Place Naming. Aldershot: Ashgate.

Birch, S. (2000): Interpreting the regional effect in Ukrainian politics. Europe-Asia Studies 52(6), 10171041, https://doi.org/10.1080/09668130050143815.

Bucher, S., Matlovič, R., Lukáčová, A., Harizal, B., Matlovičová, K., Kolesárová, J., Čermákov, L., Michalko, M. (2013): The perception of identity through urban toponyms in the regional cities of Slovakia. Anthropological Notebooks 19(3), 23-40.

Chloupek, B. R. (2019): Public memory and political street names in Košice: Slovakia's multiethnic second city. Journal of Historical Geography 64, 25-35, https:// doi.org/10.1016/j.jhg.2018.11.007.

Clem, R. S., Craumer, P. R. (2008): Orange, Blue and White, and Blonde: the electoral geography of Ukraine's 2006 and 2007 Rada elections. Eurasian Geography and Economics 49(2), 127-151, https://doi.org/10.2747 /1539-7216.49.2.127.

Crljenko, I. (2012): The renaming of streets and squares in post-Socialist Croatian towns. Language and Society 3, 230-241.

Czepczyński, M. (2008): Cultural Landscapes of PostSocialist Cities. Aldershot: Ashgate, https://doi.org /10.4324/9781315575315.
Dala Costa, A. (2020): Toponymy and the issues of memory and identity on the post-Soviet Tbilisi cityscape. The Ideology and Politics Journal 1(15), 148-171.

Diesen, G., Keane, C. (2017): The two-tiered division of Ukraine: Historical narratives in nation-building and region-building. Journal of Balkan and Near Eastern Studies 19(3), 313-329, https://doi.org/10.1080 /19448953.2017.1277087.

Fernos, Yu. (2018): Vplyv protsesu dekomunizatsiji na systemu urbanonimiv mista Umani [The influence of de-communization processes on the system of Uman urbanonyms]. Bulletin of Alfred Nobel University. Series "Philological Sciences" 2(16), 299-304, https://doi.org /10.32342/2523-4463-2018-2-16-28.

Gill, G. (2005): Changing symbols: the renovation of Moscow place names. The Russian Review, 64, 480-503, https://doi.org/10.1111/j.1467-9434.2005.00371.x.

Gnatiuk, O. (2018): The renaming of streets in postrevolutionary Ukraine: regional strategies to construct a new national identity. AUC Geographica 53(2), 119-136, https://doi.org/10.14712/23361980.2018 .13.

Gnatiuk O., Glybovets V. (2020): Do street status and centrality matter for post-socialist memory policy? The experience of Ukrainian cities. Geographia Polonica 93(2), 139-161, https://doi.org/GPol.0167.

Gnatiuk, O., Melnychuk, L. (2020): Spatial-temporal aspects of toponymy decommunization in the city of Kyiv. The Ideology and Politics Journal 1(15), 83-114, https:// doi.org/10.36169/2227-6068.2020.01.00005.

Golikov, A. (2020): (Pere)imenovanija i dekommuniozatsija po-ukrainski: makropolitiki, istoricheskaja pamiat i riski mediatizatsii (kejs Harkova) [(Re-)naming and decommunization in Ukrainian: macropolicies, historical memory and the risks of mediatization (Kharkiv case)]. The Ideology and Politics Journal 1(15), 33-62, https:// doi.org/10.36169/2227-6068.2020.01.00003.

Hrytsak, Y. (2007): Konstrujuvannia natsionalnoho mista: vypadok Lvova [Construction of a national city: case of Lviv]. Dukh i Litera 17-18, 157-181.

Hyrych, I. (2013): Suchasna toponimika Kyjeva jak vyjav istorychnoji svodomosti [Modern Kyiv place names as an expression of historical consciousness]. Natcionalna ta istorychna pamyat' $8,133-141$.

Karoyeva, T. (2017): Z dosvidu robochoji hrupy schodo dekomunizatsiji publichnoho prostoru Vinnytsi: pohliad istoryka [Abstract of practical activity of a workgroup on "decommunization" of public area of the town of Vinnytsia: historian's view]. City: History, Culture, Society 2, 196-206, https://doi.org/10.15407/mics2017 .02 .196 .

Katchanovski, I. (2006): Regional political divisions in Ukraine in 1991-2006. Nationalities Papers 34(5), 507532, https://doi.org/10.1080/00905990600952939.

Kudriavtseva, N. (2020): Reconfiguring identities within the cityscape: ideologies of decommunization renaming in Ukraine. The Ideology and Politics Journal 1(15), 63-82, https://doi.org/10.36169/2227-6068.2020.01.00004.

Lappo, G. M. (2012): Goroda Rossii. Vzgliad geografa [Cities of Russia. A Geographer's View]. Moscow: Novyi hronograf.

Light, D. (2004): Street names in Bucharest, 1990-1997: exploring the modern historical geographies of postsocialist change. Journal of Historical Geography 30(1), 
154-172. https://doi.org/10.1016/s0305 -7488(02)00102-0.

Light, D., Young, C. (2014): Habit, memory and the persistence of socialist-era street names in post-socialist Bucharest, Romania. Annals of the Association of American Geographers 104(3), 668-685, https://doi.org /10.1080/00045608.2014.892377.

Light, D., Young, C. (2017): The politics of toponymic continuity: the limits of change and the ongoing lives of street names. [In:] R. Rose-Redwood, D. Alderman, M. Azaryahu (eds.) The political life of urban streetscapes: naming, politics, and place. Abingdon, U.K.: Routledge, 185-201.

Lotman, Y. (2000 [1996]): Vnutri mysliashih mirov [Inside thinking worlds]. [In:] Y. Lotman, Semiosfera. SaintPetersburg: Iskusstvo, 150-390.

Marin, A. (2017): Toponymic changes as temporal boundary-making. Street renaming in Leningrad /St. Petersburg. [In:] R. Rose-Redwood, D. Alderman, M. Azaryahu (eds.) The political life of urban streetscapes: naming, politics, and place. Abingdon, U.K.: Routledge: 132-149.

Males, L. (2016): Dyskurs dekomunizatsiji v Kyjevi [Decommunization Discourse in Kyiv]. Sociological Studios 2(9), 16-21, https://doi.org/10.29038 /2306-3971-2016-02-16-21.

Males, L., Deineka A. (2020): Diskurs dekommunizatsii Kieva v opyte pereimenovanij [The discourse of Kyiv's decommunization in the frame of toponymic renaming]. The Ideology and Politics Journal 1(15), 115-147, https://doi.org/10.36169/2227-6068.2020.01.00006.

Marples, D. (2016): Ethnic and Social Composition of Ukraine's Regions and Voting Patterns. [In:] A. PikulickaWilczewska, R. Sakwa (Eds.) Ukraine and RussiaPeople, Politics, Propaganda andPerspectives. Bristol: E-International Relations Publishing, 8-17.

Molchanov, M. A. (2016): Russia as Ukraine's 'Other': Identity and Geopolitics. [In]: A. Pikulicka-Wilczewska, R. Sakwa (eds.) Ukraine and Russia: People, Politics, Propaganda and Perspectives. Bristol: E-International Relations Publishing, 195-210.

Neher, O. (2014). Derzhavna ideolohija jak chynnyk vplyvu na rozvytok zakarpatoukrajinskoho urbanonimikonu v kintsi XX - na pochatku XXI st. [State ideology as factor of influence on development of urbanonymy of Zakarpattya at the end of XX - in the beginning of XXI centuries]. Suchasni problem movoznavstva ta literaturoznavstva 19, 66-69.

Nikolaeva, E. V. (2014): Fraktaly gorodskoy kultury [Fractals of the urban culture]. Saint Petersburg: Strata.

O’Loughlin, J., Toal, G., Kolosov, V. (2017): The rise and fall of "Novorossiya": examining support for a separatist geopolitical imaginary in southeast Ukraine. Post-Soviet Affairs 33(2), 124-144, https://doi.org/10.1080/10605 86X.2016.1146452.

Osipian, A. L., Osipian, A. L. (2012): Regional diversity and divided memories in Ukraine: contested past as electoral resource, 2004-2010. East European Politics and Societies 26(3), 616-642. https://doi.org/10.1177 /0888325412447642.

Pavlenko, I. (2020): Deradianizatsija ta dekomunizatsija ukrajinskoho urbanimikonu (na materiali nazv objektiv miskoho prostoru Zaporizhzhia) [Desovetization and decommunization of the Ukrainian urbanimicon (on the material of Zaporizhzhia place names)]. The Ideology and Politics Journal 1(15), 188-207, https://doi.org /10.36169/2227-6068.2020.01.00009.

Palmberger, M. (2017): Nationalizing the streetscape: the case of street renaming in Mostar, Bosnia and Herzegovina. [In:] R. Rose-Redwood, D. Alderman, M. Azaryahu (eds.) The political life of urban streetscapes: naming, politics, and place. Abingdon, U.K.: Routledge: 168-184, https://doi.org/10.4324 /9781315554464-10.

Palonen, E. (2008): The city-text in post-communist Budapest: street names, memorials, and the politics of commemoration. GeoJournal 73(3), 219-230, https:// doi.org/10.1007/s10708-008-9204-2.

Palonen, E. (2017): Building a new city through a new discourse Street naming revolutions in Budapest. [In:] R. Rose-Redwood, D. Alderman, M. Azaryahu (eds.) The political life of urban streetscapes: naming, politics, and place. Abingdon, U.K.: Routledge, 98-113, https://doi.org /10.4324/9781315554464-6.

Pirie, P. R. (1996): National Identity and Politics in Southern and Eastern Ukraine. Europe-Asia Studies 48(7), 10791104, https://doi.org/10.1080/09668139608412401.

Portnov, A. (2013). Memory Wars in Post-Soviet Ukraine (1991-2010). [In:] U. Blacker, A. Etkind, J. Fedor (eds.) Memory and Theory in Eastern Europe. New York: Palgrave Macmillan, 233-254, https://doi.org/10.1057 /9781137322067_12.

Riznyk, O. (2007): Toponimichnyi landshaft Kyieva i problemy derzhavnoi toponimichnoi polityky [Toponymic landscape of Kyiv and problems of the state toponymic policy]. Retrieved from https://web .archive.org/web/20121023231457/http://www .culturalstudies.in.ua/statti_1_2007.php (accessed on 11 June 2020).

Robinson, D. (1989): The language and significance of place in Latin America. [In:] J. Agnew, J. Duncan (eds.) The Power of Place. Boston: Unwin Hyman, 157-184.

Rose-Redwood, R. (2017): From number to name. Symbolic capital, places of memory, and the politics of street renaming in New York City. [In:] R. Rose-Redwood, D. Alderman, M. Azaryahu (Eds.) The political life of urban streetscapes: naming, politics, and place. Abingdon, U.K.: Routledge, 274-289, https://doi.org /10.4324/9781315554464-16.

Rose-Redwood R., Alderman D., Azaryahu M. (2017a): Contemporary issues and future horizons of critical urban toponymy. [In:] R. Rose-Redwood, D. Alderman, M. Azaryahu (eds.) The political life of urban streetscapes: naming, politics, and place. Abingdon, U.K.: Routledge, 309-319, https://doi.org/10.4324 /9781315554464-18.

Rose-Redwood R., Alderman D., Azaryahu M. (2017b): The urban streetscape as political cosmos. [In:] R. RoseRedwood, D. Alderman, M. Azaryahu (eds.) The political life of urban streetscapes: naming, politics, and place. Abingdon, U.K.: Routledge, 1-24, https://doi.org /10.4324/9781315554464-1.

Rowland, R. H. (1983): The growth of large cities in the USSR: policies and trends, 1959-1979. Urban Geography 4(3), 258-279. https://doi.org/10.2747/0272-3638 4.3.258.

Rusu, M. S. (2020): Political patterning of urban name scapes and post-socialist toponymic change: 
A quantitative analysis of three Romanian cities. Cities 103, https://doi.org/10.1016/j.cities.2020.102773.

Savchenko, L., Takhtaulova, M. (2019): Bazovi kharakterystyky kompleksnoho istorychnoho doslidzennia toponimiky ukrajinskoho mista (na prykladi Kharkova) [Base characteristics of the Ukrainian city toponymy historical research (the Kharkiv case)]. City: History, Culture, Society 6, 121-133, https:// doi.org/10.15407/mics2019.06.121.

Shevel, O. (2011): The politics of memory in a divided society: a comparison of post-Franco Spain and postSoviet Ukraine. Slavic Review 70(1), 137-164, https:// doi.org/10.5612/slavicreview.70.1.0137.

Smirnov, S. B. (2013): Evropa i mir v toponimike Peterburga: metod analiza [Europe and the world in toponymy of St. Petersburg: a method of analysis]. Herald of Vyatka State University 4-1, 112-116.

Stewart, G. (1954): A Classification of Place Names. Names 2(1), 1-13.

Stojanović, D. (2007). Die Straßen Belgrads 1885-1914 [The streets of Belgrade 1885-1914]. [In:] U. Brunnbauer, A. Helmedach, and S. Troebst (eds.) Schnittstellen. Gesellschaft, Nation, Konflikt und Erinnerung in Südosteuropa. Munich: R. Oldenbourg, 65-79.

Stiperski, Z., Lorber, L., Heršak, E., Ptaček, P., Górka, Z., Kołoś, A., Lončar, J., Faričić, J, Miličević, M., Vujaković, A., Hruška, A. (2011): Identity through urban nomenclature: eight Central European cities. Geografisk Tidsskrift Danish Journal of Geography 111(2), 181-194, https:// doi.org/10.1080/00167223.2011.10669532.

Šakaja, L., Stanić, J. (2017): The spatial codification of values in Zagreb's city-text. [In:] R. Rose-Redwood, D. Alderman, M. Azaryahu (eds.) The political life of urban streetscapes: naming, politics, and place. Abingdon, U.K.: Routledge, 151-167, https://doi.org /10.4324/9781315554464-9.

Takhtaulova, M. (2015). Toponimika postradianskoho Kharkova: na shliakhu do dekomunizatsiji [The toponymy of the post-Soviet Kharkiv: on the way to the decommunization]. Science and Education a New Dimension. Humanities and Social Sciences 67(11), 36-39.

Takhtaulova, M. (2017): Kharkivska toponimika: etapy dekomunizatsiji [Kharkiv toponymy: stages of decommunization]. City: History, Culture, Society 1, 142-151, https://doi.org/10.15407/mics2017.02.142.

Thakahov, V. Kh. (2019): Identichnost i pamiat v toponimicheskoj politike Chechni [Identity and memory in toponymic policy in Chechnya]. Scientific Thought of Caucasus 2, 40-49, https://doi.org/10.18522 /2072-0181-2019-98-2-40-49.

Vengryniuk, L. (2012): Realizatsija polityky pamiati: rehionalnyj vymir (na prykladi m. Ivano-Frankivska) [The implementation of the politics of memory: regional dimension (example of Ivano-Frankivsk)]. Precarpathian Bulletin of the Schevchenko Scietnific Society, Dumka Series 3(19), 243-252.

Yeoh, B. (1996): Street-naming and nation-building: toponymic inscriptions of nationhood in Singapore. Area 28(3), 298-307.

Yeoh, B. (2017): Colonial urban order, cultural politics, and the naming of streets in nineteenth- and early twentiethcentury Singapore. [In:] R. Rose-Redwood, D. Alderman, M. Azaryahu (eds.) The political life of urban streetscapes: naming, politics, and place. Abingdon, U.K.: Routledge, 41-55, https://doi.org /10.4324/9781315554464-3. 